\title{
Penyebab Perilaku Cybersex dan Dampaknya pada Perilaku Mahasiswa (Studi Kualitatif di Kabupaten Jember)
}

\author{
Rizka Huwaidah \\ Fakutas Kesehatan Masyarakat Universitas Jember \\ cizkaa.29@gmail.com \\ Dewi Rokhmah \\ Fakultas Kesehatan Masyarakat Universitas Jember \\ dewirokhmah@unej.ac.id \\ Mury Ririanty \\ Fakultas Kesehatan Masyarakat Universitas Jember \\ muryririanty@yahoo.com
}

\begin{abstract}
Cybersex occurs when someone uses the internet as a medium of interaction to get sexual satisfaction. The triggers for cybersex behaviour can consist of the individual himself or a supportive environment. The purpose of this study was to analyze the causes of cybersex behaviour and its impact on student behaviour. This research is qualitative research with a case study approach. The results showed that cybersex was caused by curiosity, fun, peer influence, exposure to pornographic content advertisements, stimulation of taboo conversations from interlocutors, easy internet access, and the influence of adult films. The premarital sex behaviour carried out by the informants consisted of kissing, necking, petting, and intercourse. The impact felt by informants on cybersex behaviour was a disruption of sleep time and informants tended to stay up late at night due to cybersex. In addition, if they did not do cybersex, informants felt confused, felt that something was missing, and were anxious.
\end{abstract}

Key words: cybersex; premarital sex; addiction; college student

\begin{abstract}
Abstrak
Cybersex terjadi ketika seseorang menggunakan internet sebagai media interaksi dengan tujuan mendapatkan kepuasan seksual. Pemicu perilaku cybersex bisa terdiri dari individu itu sendiri ataupun lingkungan sekitar yang mendukung. Tujuan dari penelitian ini adalah untuk menganalisis penyebab perilaku cybersex dan dampaknya pada perilaku mahasiswa. Penelitian ini merupakan penelitian kualitatif dengan pendekatan studi kasus. Hasil penelitian menunjukkan bahwa cybersex disebabkan oleh rasa penasaran, iseng, pengaruh teman sebaya, paparan iklan berkonten pornografi, stimulus obrolan tabu dari
\end{abstract}


lawan bicara, mudahnya akses internet, serta pengaruh dari film dewasa. Perilaku seks pranikah yang dilakukan informan terdiri dari kissing, necking, petting, hingga intercourse. Dampak yang dirasakan informan atas perilaku cybersex adalah terganggunya waktu tidur dan informan cenderung terjaga hingga larut malam karena melakukan cybersex. Selain itu, apabila tidak melakukan cybersex, informan merasakan perasaan bingung, merasa ada yang kurang, dan gelisah.

Kata kunci : cybersex; seks pranikah; kecanduan; mahasiswa

\section{Pendahuluan}

Pada tahun 2017, Asosiasi Penyelenggara Jaringan Internet Indonesia (APJII, 2017) melakukan survey dengan hasil bahwa 143,26 juta penduduk Indonesia (54,68\% dari total populasi masyarakat Indonesia) telah terkoneksi ke dalam jaringan internet dan 89,35\% layanan yang diakses adalah layanan chatting. Salah satu yang menjadi perhatian dan sangat meresahkan dari perkembangan internet adalah bidang kesusilaan seperti cybersex (Monica et al., 2013). Cybersex terjadi ketika seseorang menggunakan internet sebagai media interaksi dengan orang lain dengan tujuan mendapatkan kepuasan seksual. Cybersex merupakan bentuk permainan peran yang berpura-pura atau seolah menganggap dirinya melakukan hubungan seksual secara nyata, dengan menggambarkan sesuatu yang mendorong fantasi seksual mereka (Supusepa, 2011).

Pengguna Cybersex mengalami online sexual compulsivity, yaitu ketidakmampuan untuk menolak dorongan melakukan suatu tindakan seks secara online. Perilaku cybersex mulai dari melihat gambar-gambar erotis sampai dengan chatting erotis atau komunikasi real-time dengan pasangan fantasi. Gambar-gambar dan chatting yang erotis berarti gambar dan chatting tersebut dapat menyebabkan seseorang terangsang. Ketika responden penelitian terlibat real-time dengan pasangan fantasi, mayoritas responden melakukannya dengan saling tukar menukar suara melalui media telepon (Sari et al., 2012).

Setelah melakukan studi pendahuluan dengan metode indepth interview pada mahasiswa, yakni pada 27 Oktober 2017, didapatkan hasil bahwa informan mulai mengenal cybersex sejak tahun 2012. Informan melakukan chatsex, phone 
sex hingga videocall sex dengan pasangannya dari lewat tengah malam hingga menjelang pagi. Pada saat melakukan cybersex, selain obrolan mesum, voicenote, foto serta video erotis, informan juga melakukan onani hingga hasratnya terpuaskan. Kebiasaan informan melakukan cybersex berawal dari adanya promosi invite pin BBM dari facebook yang didasari oleh rasa penasaran ingin mencoba. Selain itu, informan mengenal cybersex dari teman-teman kost infoman yang lebih berpengalaman dalam hal tersebut. Setelah terbiasa melakukan cybersex, informan akan merasakan perasaan gelisah apabila hasratnya tidak dapat disalurkan melalui cybersex.

Mahasiswa dan pelajar yang melakukan cybersex jenis chatsex kemudian melanjutkan dengan hubungan seks pranikah (Saputro, 2015). Hubungan seksual pranikah merupakan bentuk dorongan seksual yang diwujudkan melalui perilaku seks, baik itu dilakukan oleh diri sendiri, dengan lawan jenis maupun sesama jenis tanpa adanya ikatan pernikahan yang sah (Sarwono, 2016). Rokhmah dan Khoiron melakukan penelitian di wilayah Puger kabupaten Jember pada tahun 2015 dan mendapatkan hasil sebanyak 15\% dari 200 remaja telah melakukan hubungan seksual pranikah (Rokhmah et al., 2015).

Salah satu dampak dari seks pranikah adalah kehamilan yang tidak diinginkan. Hal ini disebabkan karena rendahnya tingkat pengetahuan mengenai kesehatan reproduksi serta tingginya perilaku seks pranikah (BKKBN, 2015). Selain itu, dampak negatif dari seks pranikah adalah beban mental/trauma, kehamilan yang tidak diinginkan, aborsi, penyakit kelamin, perasaan bersalah hingga perasaan takut ditinggal oleh pasangan (Taufik, 2013). Beberapa hal yang dapat menjadi faktor risiko terjadinya aktivitas seksual remaja adalah kurangnya pengawasan orang tua dan rendahnya pengawasan lingkungan. Semakin tinggi peran keluarga pada remaja, maka perilaku seks pranikah remaja semakin baik dan sebaliknya (Irmawaty, 2013).

Mahasiswa yang belum dapat menyalurkan hasrat seksualnya melalui hubungan seks, akan cenderung memiliki skeptisme yang tinggi akan praktik hubungan badan. Namun sebaliknya bagi mahasiswa yang seringkali menyalurkan hasrat seksualnya melalui hubungan seksual akan cenderung 
menjadikan praktik hubungan badan sebagai kebiasaan (Saputro, 2015). Selain perilaku seks pranikah, mahasiswa sebagai kelompok akademisi juga berisiko tinggi untuk mengalami gangguan kecanduan internet. Hal ini tidak lepas dari tingginya intensitas mahasiswa untuk mengakses internet. Apabila tidak mampu berhati-hati, bukannya bermanfaat tetapi akan menjerumuskan mahasiswa yang bersangkutan dalam penggunaan internet yang negatif dan menimbulkan kecanduan tersebut (Basri, 2014). Berdasarkan uraian diatas, maka perlu diadakan penelitian terkait penyebab dari perilaku cybersex hingga dampaknya terhadap perilaku seks pranikah pada mahasiswa.

\section{Metode}

Penelitian ini menggunakan penelitian kualitatif dengan pendekatan studi kasus. Penelitian dilakukan di Kabupaten Jember, pada bulan Oktober 2017 sampai Juli 2018. Waktu penelitian dihitung dari dilakukannya studi pendahuluan hingga penyusunan laporan hasil penelitian. Informan pada penelitian ini dipilih berdasarkan teknik purposive sampling. Jumlah informan sebanyak 7 orang, 5 orang sebagai informan utama dan 2 orang sebagai informan tambahan. Informan utama dipilih berdasarkan kriteria: mahasiswa, belum menikah, pernah melakukan cybersex dalam kurun waktu 6 bulan terakhir sebelum wawancara, dan bersedia menjadi informan utama. Penelitian dilakukan dengan teknik wawancara secara langsung menggunakan panduan wawancara, dokumentasi dan observasi.

\section{Hasil Dan Pembahasan}

Pada umumnya dalam melancarkan praktik cybersex dengan metode chatsex, mahasiswa memanfaatkan media komunikasi berupa handphone, laptop ataupun personal computer (PC) (Saputro, 2015). Seperti yang dikatakan oleh salah satu informan :

"Hp mbak, kalo dirumah pakai hp aja sinyale lemot, nek pake laptop orang disini gak pakai wifi, maupake modem tambah gimana sinyale”

Handphone dipilih untuk digunakan karena jauh lebih mudah dan ringkas dalam penggunaannya. Penyebab lain yang membuat handphone menjadi pilihan 
untuk digunakan oleh para informan adalah sifatnya yang praktis untuk dibawa ke mana- mana. Kemudahan penggunaan, adanya ruang privacy yang bisa didapatkan dan akses internet untuk kemudahan komunikasi membuat informan semakin memilih handphone. Selain itu, handphone memiliki fasilitas pendukung seperti Internet yang menawarkan berbagai situs yang menyediakan berbagai hal seperti media sosial yang sangat populer pada masyarakat (Kogoya, 2015). Penggunaan pengiriman pesan melalui Short Message Service (SMS) mulai tergantikan dengan penggunaan aplikasi- aplikasi pengiriman pesan yang lebih modern.

“....Kalau chat itu kan dulu awal-awal itu cuma lewat SMS, telepon biasa. Pas sekarang udah aplikasi online itu seringnya ya pake wa"

Seiring dengan perkembangan zaman, SMS yang dulu sering digunakan untuk berkomunikasi sudah mulai berganti menggunakan aplikasi WhatsApp. Berdasarkan hasil penelitian, selain menggunakan aplikasi media sosial seperti WhatsApp, Line dan BlackBerry Messenger (BBM). Namun, sebagian informan juga ada yang masih memilih menggunakan telepon biasa dengan berbayar pulsa, bukan aplikasi yang terhubung dengan internet. Hal ini dikarenakan alasan kelancaran dan kejelasan dalam berkomunikasi. Pada wilayah-wilayah tertentu, jaringan internet cepat dan stabil masih belum bisa dinikmati.

Rasa penasaran terhadap hubungan seksual dan bagian-bagian tubuh lawan jenis juga dirasakan oleh informan sebagai faktor pendorong mereka memanfaatkan media pornografi (Masroah et al., 2015). Media pornografi yang digunakan oleh para informan berkembang menjadi media komunikasi yang di gunakan sebagai perantara obrolan seks antar individu. Perkembangan ini biasanya mampu menimbulkan rasa ingin coba-coba pada informan. Seperti pada kutipan berikut :

"Pertama kali awalnya ya penasaran banget, kok kayak seru banget gitu. Penasaran kan, terus akhire terpancing itu sama mbahas-mbahas itu. Ini kan hal baru banget bagi saya, gak pernah sebelumnya, belum pernah ngerasain, kayak gimana, kayak apa, pengen tau, pengen nyoba, yaudah wes keterusan itu dah"

Pembahasan yang mengarah pada ranah seks melalui perantara gadget merupakan hal yang baru bagi para informan, sehingga dari situlah rasa 
penasaran ingin mencari tahu lebih jauh muncul. Didukung dengan situasi serta kondisi lain yang juga dijadikan pertimbangan, membuat para informan akhirnya berani mengambil keputusan. Keputusan yang diambil tentunya juga mempertimbangkan feedback dari lawan komunikasi. Seperti yang disampaikan dalam kutipan berikut :

“...Awale aku merasa gak enak, tapi lama-kelamaan ya itu. Gini ya, kalau misal aku sama dia kan dua orang ya, kalau dianya gak mau, gak enak dan ga nyaman, otomatis kan aku gak bakal mau lanjutin atau nerusin. Nah karena aku sama dia sama-sama ngerasa nyaman dan enak, makanya itu terus bisa lanjut".

Selain rasa penasaran, ada lagi keinginan untuk menanggapi pasangan dan pertimbangan lain dalam berkomunikasi, seperti apakah lawan bicara bisa dan mau memberikan feedback seperti yang diharapkan atau tidak. Rasa ketidaktahuan terkait pembahasan berbau seksual, membuat informan merasa kikuk dan sedikit takut untuk mencoba melanjutkan obrolan. Terjadinya cybersex juga ada yang diawali dari rasa iseng dan keinginan untuk membahas yang menjurus ke arah konten seksual. Keinginan untuk menanggapi muncul seiring dengan rasa penasaran terhadap sesuatu yang baru dan dirasa menarik. Apabila dirasa saling nyaman, maka pembahasan akan bisa terus berlanjut dan menjadi sebuah kebiasaan.

Lingkungan sosial yaitu lingkungan atau orang lain yang dapat mempengaruhi diri seseorang baik secara langsung maupun secara tidak langsung (Annajah et al., 2016). Ketersediaan dan kemudahan menjangkau produk media massa dapat membangkitkan nafsu birahi secara seksual, hal ini merupakan faktor stimulan utama untuk melakukan perilaku tersebut di dunia nyata (Sari et al., 2012). Lingkungan sosial bisa berupa teman sebaya yang menjadi kawan bermain.

“..... Kelas lima SD itu udah mulai kenal itu. Pertama kali kenal itu ya, dikasih tau temen. Jadi kayak diajak maen pas pulang sekolah itu kan dulu di warnet, nah diajak ke warnet itu kan aku gak tau..."

Informan yang awalnya belum pernah terpapar terkait pornografi lamakelamaan menjadi menerima, senang, bahkan ketagihan dengan tayangan tersebut dikarenakan seringnya informan terpapar dengan tayangan pornografi. Semakin banyak mendengar, melihat dan bahkan mengalami hubungan seksual 
maka semakin kuat stimulasi yang mendorong munculnya perilaku seksual tersebut, misalnya melihat gambar-gambar porno di internet ataupun mendengar obrolan dari teman mengenai pengalaman seksual (Fauziah et al., 2017).

Semakin bertambahnya usia dan pergaulan yang dilewati, banyak hal yang mampu mempengaruhi perilaku. Belajar dan mengadopsi hal-hal baru bukan tidak mungkin untuk dilakukan. Seberapa banyak pengaruh teman sebaya terhadap perkembangan seseorang tergantung pada seberapa cepat budaya sekitar mereka berkembang (Ritonga et al., 2012). Bagi mahasiswa yang tinggal dengan kost dan sejenisnya, keluarga baru mereka adalah orang-orang yang tinggal dalam satu lingkungan dengan mereka. Dengan kata lain, keberadaan kawan kost menjadi kunci penting dalam terbentuknya perilaku baik atau buruk seseorang. Seperti yang ada pada kutipan berikut :

“...Ya itu awal mula liat video gitu-gitu di internet, terus juga dari temen saya itu hampir tiap hari lihat video begituan. Akhirnya satu asrama ikut kabeh, kok awale ada suara-suara ngene, akhire penasaran, terus lihat dah satu asrama."

Kondisi lingkungan sekitar mampu secara langsung mempengaruhi kehidupan dari orang-orang yang tinggal pada lingkungan tersebut, termasuk remaja. Remaja yang terpapar oleh keadaan yang tidak ideal untuk mendukung pertumbuhan dan perkembangan mereka, akan berakibat pada terbiasanya mereka dalam lingkungan yang permisif terhadap suatu hal yang menjadi kebiasaan pada lingkungan tersebut. Pada kasus ini adalah kebiasaan dalam menonton video porno (Rokhmah et al., 2015). Intensitas penggunaan internet oleh para remaja dianggap mempunyai pengaruh yang sangat kuat terhadap pembentukan karakter (Ritonga et al., 2012).

“.... Kelas lima SD itu udah mulai kenal itu. Pertama kali kenal itu ya, dikasih tau temen. Jadi kayak diajak maen pas pulang sekolah itu kan dulu di warnet, nah diajak ke warnet itu kan aku gak tau..."

Informan pertama kali mengenal hal-hal berkonten pornografi adalah saat kelas 5 SD. Hal ini menunjukkan bahwa kemudahan dari internet juga bisa menimbulkan dampak buruk. Salah satunya adalah kemudahan mengakses internet terkait hal-hal yang berkonten pornografi, bahkan oleh anak-anak sekalipun (Dinesh et al., 2016) 
Selain dari media, dorongan eksternal juga bisa berasal dari lawan komunikasi yang didapatkan oleh informan. Lawan komunikasi dari informan berperan penting sebagai faktor yang mempengaruhi dalam pengambilan keputusan. Stimulus berupa obrolan yang mengusung konten berbau pornografi apabila diberikan secara terus- menerus dan intens, akan mampu menimbulkan rasa penasaran dan keinginan untuk menanggapi dari dalam individu. individu yang mengakses materi seksual bertujuan untuk memenuhi rasa ingin tahu atau untuk hiburan dan merasa puas dengan ketersediaan materi seksual yang diinginkan (Sari et al., 2012).

Beberapa bentuk perilaku cybersex: mengakses pornografi di internet (seperti gambar, video, cerita teks, majalah, film, dan game); mengakses pornografi multimedia software yang tidak harus online (seperti menonton VCD/DVD yang berisi film porno dan memainkan game porno di laptop atau komputer) dan Real time dengan pasangan (chatsex, phone sex dan videocall sex) (Sari et al., 2012). Pada penelitian ini, peneliti mengkhususkan pembahasan pada cybersex jenis Real time dengan pasangan. Dimana komunikasi yang terdiri dari dua orang atau lebih yang saling memberi feedback dalam obrolan tersebut. Berikut adalah kutipan dari hasil wawancara yang menunjukkan jenis perilaku cybersex seperti apa yang digunakan oleh informan :

"Pake semuanya sih aku, dari chat, telepon sama vc itu pake. Tapi kalau pake chat itu yang paling sering. Kalau chat itu kan dulu awal-awal itu cuma lewat SMS, telepon biasa. Pas sekarang udah aplikasi online itu seringnya ya pake $w a "$

Jenis cybersex yang pernah dilakukan oleh informan yaitu melalui chat, telepon maupun videocall. Cybersex yang dilakukan melalui chatting, akan memunculkan fantasi seks yang semakin parah. Karena kedua pasangan samasama saling merangsang, maka mereka akan merasa seolah-olah benar-benar berhubungan seks dengan partner online-nya (Irawanto, 2017).

Pemilihan penggunaan chatting melalui beberapa pertimbangan, seperti kuota yang dihabiskan lebih sedikit dan lebih cepat dalam berkomunikasi. Tidak hanya lewat tulisan yang berupa obrolan jorok, aktivitas chatting juga berisi saling mengirim gambar, foto dan voicenote yang mampu membangkitkan 
imajinasi dari masing-masing pasangan. Berikut kutipan jawaban informan saat menceritakan proses melakukan cybersex dengan pasangan masing-masing :

“...Kalau foto itu ya fotonya payudaranya dia, kemaluannya dia, terus kadang saya minta dia pose gini-gini, ya itu. Kalo yang vn itu, saya biasanya minta dia desah-desah gitu biar makin kerasa nyata. Kadang bunyi kayak dia ngemut atau jilat jilat gitu, wiih imajiinasi tambah liar itu..."

"Kalau videocall kan ya paling juga gak beda jauh sama yang udah pernah samean wawancarain, tapi kalau aku itu ya biasanya itu biasanya cuma si cewe, ya maaf ya. Si cewek nyuruh aku apa telanjang, gitu ya aku telanjang....Jadi ya gitu itu kan pas telfon kayak by request gitu, pengennya gimana. Kalo telfon ya sama isinya, cuman gak keliatan orangnya, gitu aja"

Pada saat melakukan phonesex ataupun videocallsex, para informan saling melakukan obrolan seks satu sama lain, ditambah dengan masturbasi untuk mencapai kepuasan seksual. Bedanya dengan telepon, videocall menggunakan alat tambahan berupa webcam yang membantu pengguna untuk dapat memperlihatkan anggota tubuhnya satu sama lain. Dengan seperti itu, aktifitas sex online mampu dilakukan secara digital tanpa harus melakukan kontak fisik antara kedua pihak (Muttaqin, 2009). Saat melakukan videocallsex, para informan bisa melihat pasangan mereka bermasturbasi, begitupula sebaliknya.

Pasangan dalam melakukan cybersex tidak selalu pasangan atau pacar di dunia nyata. Selain pacar, pasangan cybersex juga bisa berasal dari teman tanpa ada status pacar atau pasangan di dunia nyata, bahkan bisa juga dari orang yang tidak dikenal. Seperti pada kutipan berikut:

“....Dulu pernah tuh pas kuliah semester berapa ya kemaren ini, ada nomer nyasar teryata tante tante gitu ya tak ladenin, wong dianya yang goda kirimkirim foto vulgar gitu, fotonya dia yang seksi seksi, lah ya gak nolak mbak..."

Media sosial semakin memudahkan siapapun bisa berteman dan berkomunikasi. Tidak perlu harus saling mengenal terlebih dahulu untuk bisa mendapatkan kesempatan untuk saling berkomunikasi. Kemudahan yang dihadirkan oleh perkembangan internet salah satunya adalah meniadakan batasan-batasan dalam berkomunikasi, seperti ruang dan waktu. Setiap orang bisa saling berkomunikasi tanpa harus melakukan pertemuan secara langsung di dunia nyata.

Pada wilayah Puger, kabupaten Jember didapatkan hasil sebanyak $15 \%$ 
remaja telah melakukan hubungan seksual. 6\% diantaranya menggunakan kondom, hanya $7 \%$ remaja yang melakukan hubungan dengan pacar, 2\% melakukan hubungan dengan pekerja seks komersial (PSK), 5\% remaja melakukan hubungan seksual dengan lebih dari satu orang, ada $47 \%$ remaja yang pernah melakukan masturbasi dan 5\% remaja mengalami gejala infeksi menular seksual. Berdasarkan hasil penelitian dengan teknik indepth interview, semua informan pada penelitian ini pernah melakukan kissing dan petting (Rokhmah et al., 2015).

"Ciuman? Itu mulai SMA saya, semua SMA. Cuma yang seks langsung itu mulai kuliah semester 3. Kan awalnya ciuman itu, terus turun ke leher, raba-raba ya wes terus wes"

Seluruh informan sudah mulai mengenal perilaku seks pranikah dari tingkat sekolah menengah. Bahkan ada salah satu informan yang sudah mulai berciuman sejak pacaran di tingkat Sekolah Menengah Pertama (SMP). Hal ini terjadi karena di lingkungan tempat tinggalnya, perilaku berpacaran yang seperti itu sudah lazim ditemukan. Itulah yang membuat banyak anak lain yang ikut meniru. Peniruan perilaku dapat berupa perilaku hubungan seksual baik yang ringan seperti ciuman, pelukan, hingga perilaku seksual berat seperti hubungan intim. Perilaku seks pranikah disebabkan oleh rangsangan secara terus-menerus melalui materi-materi seksual di media cetak, internet, serta teman sebaya (Yutifa et al., 2015).

Dari semua informan, perilaku seks pranikah yang dilakukan bukanlah dampak dari perilaku cybersex. Hal ini dikarenakan perkembangan teknologi yang mampu menjadi perantara cybersex baru muncul dalam kurun waktu beberapa tahun terakhir. Sedangkan perilaku seks pranikah yang ada, sudah jauh lebih dulu dilakukan oleh masing-masing informan. Meskipun cybersex bisa digunakan sebagai pemuas kebutuhan dalam aktivitas seksual, tidak ditemukan bukti bahwa para pengguna atau bahkan pecandu cybersex juga pecandu aktivitas seksual (Weinstein et al., 2016). Selain itu, berdasarkan hasil penelitian, ada beberapa informan yang tidak melakukan seks pranikah dengan pasangan dalam melakukan cybersex.

Adiksi atau kecanduan merupakan tingkah laku yang bergantung atau 
keadaan yang terikat yang sangat kuat secara fisik maupun psikologis dalam melakukan suatu hal, dan ada rasa yang tidak menyenangkan apabila hal tersebut tidak bisa terpenuhi. Sedangkan kecanduan cybersex adalah suatu keadaan seseorang yang terikat pada kebiasaan yang sangat kuat dan tidak bisa lepas untuk melakukan cybersex, terjadi peningkatan frekuensi, durasi dan jumlah dari waktu ke waktu tanpa memperdulikan konsekuensi-konsekuensi negatif yang akan timbul. Laier et al., (2013) menyatakan bahwa cybersex dapat menjadi pengganti dari kontak seksual di kehidupan nyata dan berpotensi mengakibatkan kecanduan. Berdasarkan hasil indepth interview, diketahui bahwa durasi dari penggunaan internet semakin lama menjadi semakin panjang. Seperti pada kutipan di bawah ini:

"Semakin hari semakin lama biasae, haha"

Durasi lama waktu dalam melakukan cybersex tidak dapat dipastikan. Hal itu sesuai dengan panjangnya pembahasan dari setiap pasangan. Terkadang, apabila dirasa sudah cukup maka sudah bisa diakhiri pembahasannya.

"Waah gak tentu itu. Kan se moodnya, se selesainya. Kadang cuman 15 menit, kadang 30 menit gitu. Seenaknya kan mbak, gak bisa dipastiin berapa dan kapan keluarnya, eh selesainya"

Greenfield mengatakan bahwa, yang diklasifikasikan sebagai pengguna online yang mengalami ketergantungan adalah yang menggunakan internet secara berlebihan, dan menghabiskan waktu selama 40-80 jam perminggu dengan sesi-sesi yang bisa memakan waktu 20 jam. Pola tidur mereka terganggu akibat kegiatan online larut malam, dan pecandu pada umumnya terjaga hingga larut malam untuk berselancar di internet (Young et al., 2017).

"Gak ada. Ya sama Haha ini yang paling sering semenjak saya putus itu sampai sekarang. Eh itu malah sebelum saya putus deng kayaknya. Ya, mulai dari chatting, telepon sampai videocall. Malah hampir tiap hari, tiap saat, gak peduli pagi siang malam. Kadang sampe baru tidur subuh itu”

Berdasarkan hasil penelitian, dari total 7 informan yang terdiri dari 5 informan utama dan 2 informan tambahan, terdapat 4 orang yang termasuk aktif dalam melakukan cybersex. Aktif yang dimaksudkan adalah durasi melakukan cybersex tergolong jauh lebih banyak dibandingkan yang lain. Hal ini menyebabkan waktu tidur informan menjadi bergeser, dan sering terjaga hingga 
larut malam. Hal ini sejalan dengan Laier et al. (2013) yang menyatakan bahwa beberapa orang yang mengalami kecanduan cybersex mengalami permasalahan dalam mengatur dan mengontrol aktivitas cybersex mereka, disertai dengan tidak tidur, melupakan janji hingga mengabaikan tanggung jawab.

Selain itu, apabila tidak melakukan cybersex, informan merasakan perasaan bingung, merasa ada yang kurang, dan gelisah. Seiring dengan meningkatnya rasa keingintahuan terhadap seksualitas dan pornografi, maka frekuensi memanfaatkan media untuk hal-hal berkonten pornografi ikut meningkat. Jika dikaitkan dengan perilaku seksual, maka seiring waktu dan meningkatnya frekuensi mengakses pornografi membuat keinginan untuk berperilaku seksual dan mencoba apa yang dilihat dari pornografi sangat tinggi (Masroah et al.;250). Beberapa informan yang diindikasikan mengalami kecanduan menyebutkan bahwa apabila tidak bisa melakukan cybersex pada saat yang diinginkan, akan timbul perasaan gelisah dan tidak nyaman. Perasaan gelisah dan tidak nyaman itu akan berujung pada mengakses konten pornografi sendiri di internet.

"Yaa gelisah, samean kalo misal pengen apa gak keturutan itu kan gitu, gelisah, bingung, sumpek. Nah terus ngakses sendiri akhirnya"

Hal ini sesuai dengan aspek-aspek kecanduan internet menurut Young et al. (2017) yang meliputi beberapa hal berikut ini: perhatian tertuju pada aktivitas online; ingin bermain internet dalam jumlah waktu yang semakin meningkat untuk mendapatkan kepuasan; tidak dapat mengontrol, mengurangi atau menghentikan kegiatan berinternet; merasa gelisah, tertekan, lekas marah ketika mengurangi atau menghentikan penggunaan internet; online lebih lama dari waktu yang direncanakan; menjadikan internet sebagai cara untuk melepaskan diri dari berbagai permasalahan atau melepaskan diri dari perasaan yang tidak menyenangkan; selalu kembali menggunakan internet walaupun sudah banyak menghabiskan; kecenderungan untuk menarik diri ketika offline; berani mengambil resiko kehilangan hubungan dengan orang terdekat, pekerjaan, pendidikan, atau karir karena bermain internet; berbohong terhadap anggota keluarga untuk mengurangi timgkat hubungan bermain internet. Young et al. 
(2017) juga mengatakan bahwa daya tarik internet adalah unpredictability dan tingkat pembaruan yang tinggi. Kebanyakan, individu yang menggunakan internet berada dibawah pengaruh alam bawah sadar, sehingga waktu yang dihabiskan ketika menggunakan internet terasa lebih lama ataupun lebih singkat dari waktu yang sesungguhnya. Dibandingkan yang lainnya, penggunaan internet dalam konten seksual mampu menyebabkan seseorang mengekspresikan emosi dengan sangat aktif dan tanpa berpikir panjang dalam memutuskan sesuatu. Selain itu, semua informan mengaku pernah mengakses konten pornografi.

\footnotetext{
"Oiya, hahaha. Ya video itu, di instagram itu juga ada foto foto pake bikini yang itunya keliatan besar, sama di web web yang belum di blokir. Sini nanti kalau mau nanti saya akseskan. Hahaha”
}

Bahkan pada salah satu informan, ada yang mengoleksi video porno yang biasa dilihat ketika luang. Video porno yang dikoleksipun terdiri dari berbagai macam jenis dan durasi. Selain itu, konten pornografi yang diakses biasanya dilakukan saat kebutuhan cybersex tidak dapat tersalurkan. Selain dengan paket data, akses internet juga bisa melalui wifi.

\footnotetext{
"Biasanya bergiga giga abisnya itu. Aku inget kemaren itu di kos kan pakai wifi, misal itu sekali download aku abis 3-4 Giga. Aku pernah inget sebulan itu 5 Giga lebih. Itu ukurannya kan biasanya sampai 600 Mb, 800Mb. Kadang juga misal sekali download bisa sampai 20 file..."
}

Definisi kecanduan cybersex adalah suatu keadaan seseorang yang terikat pada kebiasaan yang sangat kuat dan tidak bisa lepas untuk melakukan cybersex, terjadi peningkatan frekuensi, durasi dan jumlah dari waktu ke waktu tanpa memperdulikan konsekuensi-konsekuensi negatif yang akan timbul. Berdasarkan definisi tersebut, maka dari hasil penelitian didapatkan dari 5 informan utama, terdapat 3 informan utama yang masuk dalam kategori kecanduan. Kategori yang dimaksud adalah informan tidak bisa lepas untuk melakukan cybersex, terjadi peningkatan frekuensi, durasi dan jumlah dari waktu ke waktu. Pola tidur yang terganggu akibat kegiatan online hingga larut malam, dan umumnya terjaga hingga larut malam untuk berselancar di internet. Sedangkan apabila informan tidak bisa melakukan cybersex pada saat yang diinginkan, akan timbul perasaan gelisah dan tidak nyaman. Perasaan gelisah dan tidak nyaman itu akan berujung pada mengakses konten pornografi sendiri di internet. 


\section{Simpulan Dan Saran}

Keinginan yang muncul dari dalam individu dalam melakukan cybersex berupa rasa penasaran dan rasa ingin menanggapi obrolan mesum dengan pasangan; adanya pengaruh dari lingkungan sosial berupa teman yang berperan dalam perilaku cybersex yang dilakukan; serta adanya stimulus dari lingkungan eksternal yang berupa stimulus dari lawan komunikasi, kemudahan internet, iklan dari media sosial dan adanya pengaruh dari film porno yang pernah dilihat oleh informan.

Perilaku cybersex yang dilakukan oleh informan terdiri dari chatsex, phonesex, dan videocall sex. Seluruh informan pernah melakukan cybersex dengan jenis chatsex, dan hanya sebagian kecil informan yang pernah melakukan ketiganya. Informan menggunakan handphone sebagai alat untuk melakukan cybersex. Pasangan dalam melakukan cybersex tidak selalu pacar, namun ada juga yang melakukannya dengan teman dan orang yang tidak dikenal.

Perilaku seks pranikah yang telah dilakukan oleh seluruh informan adalah kissing dan petting. Sebagian besar pernah melakukan necking, dan sebagian kecil dari informan pernah melakukan hingga tahapan intercourse. Namun dari seluruh informan mengatakan bahwa seks pranikah yang dilakukan jauh sebelum masuknya teknologi yang mendukung perilaku cybersex.

Kecanduan yang dialami oleh sebagian besar informan dapat dilihat dari terganggunya waktu tidur yang disebabkan oleh sering terjaga hingga larut malam untuk melakukan cybersex. Pada sebagian informan juga muncul perasaan seperti ada sesuatu yang kurang dan gelisah apabila tidak bisa melakukan cybersex. Selain itu, sebagian sebagian informan melakukannya dengan rentang waktu yang terlalu dekat, sekitaran 3-7 kali dalam seminggu.

Penelitian ini tidak lepas dari kekurangan dan kesalahan sehingga diperlukan penelitian selanjutnya untuk menyempurnakan penelitian ini. Peneliti selanjutnya diharapkan dapat melakukan penelitian terkait perkembangan dampak buruk dari perilaku cybersex yang telah terjadi di lingkungan sekitar. Bisa difokuskan pada dampak cybersex terhadap risiko kesehatan remaja, seperti 
penularan Infeksi Menular Seksual (IMS) yang termasuk HIV.

\section{DAFTAR PUSTAKA}

Annajah, U. \& Nailul F.. 2016. Pengaruh Lingkungan Sosial terhadap Motivasi Berprestasi Anak Panti Asuhan Nurul Haq Yogyakarta. Jurnal Hisbah Vol. 13(1) hal. 102-115

APJII. 2017. Infografis Penetrasi dan Perilaku Pengguna Internet Indonesia survey 2017. Jakarta: APJJI

Basri, A. S. H.. 2014. Kecenderungan Internet Addiction Disorder Mahasiswa Fakultas Dakwah dan Komunikasi Ditinjau dari Religiositas. Jurnal Dakwah Vol. 15 (2)

BKKBN. 2015. RENSTRA BKKBN tahun 2015-2019. Jakarta: BKKBN

Dinesh et al.. 2016. The effect of internet uses on youth. International Journal of Applied Research Vol. 2(1)

Fauziah, A. N.. \& Siti M.. 2017. Pengaruh Umur dan Tingkat Pendidikan terhadap Perilaku Seks Pranikah pada Remaja di Rw 03 Kelurahan Mojosongo Surakarta. Indonesian Journal on Medicine Science Vol. 4 (2)

Irawanto, B. 2017. Mereguk kenikmatan di dunia maya vitualitas dan penabuhan dalam cybersex. Jurnal Kawistara Vol. 7 (1) hal. 30-40

Irmawaty, L. 2013. Perilaku Seksual Pranikah pada Mahasiswa. Jurnal Kesehatan Masyarakat Vol. 9 (1) hal. 44-52

Kogoya, D.. 2015. Dampak Penggunaan Handphone pada Masyarakat (Studi pada Masyarakat Desa Piungun Kecamatan Gamelia Kabupaten Lanny Jaya Papua. e-journal “Acta Diurna” Vol. 4 (4)

Laier et al.. 2013. Cybersex addiction: experienced sexual arousal when watching pornography and not real-life sexual contact makes the difference. Journal of behavioral addictions Vol. 2 (2) hal. 100-10

Masroah, I. T., Elviera G., \& Bambang H.. 2015. Perilaku Seksual Remaja akibat Paparan media Pornografi. Jurnal Kesmasindo Vol. 7 (3) hal. 244-255

Monica, D. R. \& Diah G. M.. 2013. Cybersex dan Cyberporn Sebagai Delik Kesusilaan. Fiat Justitia Jurnal Ilmu Hukum Vol. 7 (3) hal. 337-344

Priyoto. 2015. Perubahan dalam Perilaku Kesehatan. Graha Ilmu: Yogyakarta 
Ritonga S. \& Wira A.. 2012. Pengaruh Media Komunikasi Internet terhadap Pola Perilaku Anak di bawah 17 Tahun. Perspektif vol. 5 (2)

Rokhmah, D. \& Khoiron. 2015. The Role of Sexual Behavior In Transmission of HIV and AIDS In Adolescent In Coastal Area. Journal Procedia Environmental Sciences Vol. 23 hal. 99-104

Saputro, S.. 2015. Perilaku Seks Pranikah Mahasiswa Pengguna Jasa Cybersex di Kota Semarang. Jurnal Kesehatan Masyarakat (e-Journal) Vol. 3 (3)

Sari, N. \& Ridhoi M.P.. 2012. Gambaran Perilaku Cybersex pada Remaja Pelaku

Cybersex di Kota Medan.Psikologia-online Vol. 7 (2) hal. 62-73

Sarwono. 2016. Psikologi Remaja. Edisi Revisi. Jakarta:

Rajawali Press.

Septalita, A. \& Peter A.. 2015. Pengaruh Program Perubahan Perilaku Ibu Hamil (Cerdigi) Berdasarkan Teori ABC (Studi Pendahuluan di Kelurahan Serpong, Tangerang Selatan). Majalah Kedokteran Gigi Indonesia Vol. 1 (2) hal. $201-207$

Supusepa, R. 2011. Kebijakan Kriminal dalam Menanggulangi Kejahatan Kesusilaan yang Bersaranakan Internet (Cyber Sex). Jurnal sasi Vol.17 (4)

Taufik, A. 2013. Persepsi Remaja terhadap Perilaku Seks Pranikah (Studi Kasus SMK Negeri 5 Samarinda). eJournal Sosiatri-Sosiologi Vol. 1 (1) hal: 3144

Weinstein, A. M. et al.. 2016. Factors predicting cybersex use and difficulties in forming intimate relationships among male and female users of cybersex. Frontiers in Psychiatry Vol. 6 (54)

Young, K. S. \& Cristiano N. A.. 2017. Kecanduan Internet: panduan konseling dan petunjuk untuk evaluasi dan penanganan. Yogyakarta: Pustaka Pelajar

Yutifa, H., Ari P. D., \& Misrawati. 2015. Hubungan Paparan Pornografi Melalui Elektronik terhadap Perilaku Seksual Remaja. JOM vol. 2 (2) hal.11411148 